\title{
Must an Inventor "Possess" an Invention to Patent It?
}

\author{
Warren D. Woessner and Robin A. Chadwick \\ Schwegman, Lundberg \& Woessner, Minneapolis, Minnesota 55402 \\ Correspondence:wwoessner@slwip.com
}

The requirements for patenting inventions relating to biotechnology have become increasingly strict and complicated in recent years. Despite early patent rulings that there is no need for an inventor to "reduce to practice" an invention, the courts are now ruling that an inventor must "possess" his or her invention before filing for patent. This review discusses what such "possession" may mean and describes decisions in which courts have found that an inventor has met or failed the possession test before filing for patent protection.

S equencing of the human genome has temptSed us with the possibility of understanding the workings of life. With the structures of life's molecules in hand, scientists the world over have sought to identify what function can be tied to which (now available) molecular structure. However, a focus on function increasingly does not provide a patent applicant with a patent. Instead, the evolving judicial law on the "written description requirement" (WDR) requires that patent applicants not only describe structural, functional, and synthesis information about an invention, but also show that the applicant had "possession" of the invention before filing a patent application. Patent applicants are now denied a patent for the molecules of life, because such molecular structures are known, and also because the WDR for "mere" discovery of a function for those molecules may not confer patentability. This review describes what the courts have been saying about the WDR and shows readers how to avoid at least some WDR problems.

\section{Ariad v. Lilly COMES DOWN (ON US)}

In 2009, as the biotech industry began to be viewed as nearly "mature," a major legal battle arose in the Ariad Pharmaceuticals, Inc. v. Eli Lilly and Co. (F.3d 1336, 1341) (Fed. Cir. 2010) (en banc) case over whether the WDR exists at all. The battle lines were sharply drawn among the judges of the Court of Appeals for the Federal Circuit over whether the WDR was part of, or separate from, the "enablement" requirement for disclosure of how to make and use the invention.

The basis for the WDR and enablement requirement is found in the patent statutes of 35 U.S.C. $\$ 112(1)$, which specifies that a patent application "shall contain a written description of the invention, and of the manner and process of making and using it, in such full, clear, concise, and exact terms as to enable any person skilled in the art to which it pertains...to make and use the

Editors: Salim Mamajiwalla and Rochelle Seide

Additional Perspectives on Intellectual Property in Molecular Medicine available at www.perspectivesinmedicine.org

Copyright (C) 2014 Cold Spring Harbor Laboratory Press; all rights reserved; doi: 10.1101/cshperspect.a020867

Cite this article as Cold Spring Harb Perspect Med 2014;4:a020867 
W.D. Woessner and R.A. Chadwick

same." ${ }^{1}$ Hence, the issue in the Ariad v. Lilly case was whether a WDR existed at all or whether $\$ 112$ (1) only required a description of how to make and use the invention (enablement).

Before the Ariad v. Lilly case, the Federal Circuit was split on this issue. One camp, led by Judge Rader, argued that the WDR is no more than a semantic test-if the language used to claim the invention was recited in the patent application, the WDR is satisfied, without more. They argued that the key test under $\$ 112$ (1) was the enablement requirement and that this test is resolved by application of the very fact-specific "Wands factors" that include the nature of the invention, the breadth of the claims, the level of ordinary skill in the art, the level of predictability in the art, and the amount of direction provided by the inventor (In re Wands (858 F.2d 731) (Fed. Cir. 1988)).

The other camp, led by Judges Lourie and Newman, expected more from the WDR. Along with the enablement requirement, the majority ruled that "possession" of the invention was required to satisfy the WDR.

The Ariad v. Lilly court ruled that $\$ 112(1)$ does contain a written description requirement. However, the judges disagreed about what that requirement was.

Judge Lourie spoke for the Ariad v. Lilly majority when it held that claims of U.S. Patent No. $6,410,516$, directed to reducing NF- $\kappa \mathrm{B}$ activity in cells, were invalid for failure to meet the WDR. The judges' concern had not changed in the 15 years since The Regents of the University of California v. Eli Lilly \& Co. (119 F.3d 1559, 1568) (Fed. Cir. 1997) was decided-how to rein in "overly broad" claims based on discoveries or results that are not fully realized and thereby discourage patent claims drawn to function rather than to tangible structures to perform that function. In the UC v. Lilly case, the Federal Circuit ruled that claims to DNA encod-

\footnotetext{
${ }^{1}$ Written description 35 U.S.C. $\$ 112(1)$ : The specification shall contain a written description of the invention, and of the manner and process of making and using it, in such full, clear, concise, and exact terms as to enable any person skilled in the art to which it pertains, or with which it is most nearly connected, to make and use the same....
}

ing human insulin were invalid because the University of California patent only disclosed the sequence of rat insulin and did not show "possession" of a genus of mammalian (and human) insulin DNA sequences. The Ariad v. Lilly decision reiterated the UC $v$. Lilly WDR standards requiring definition of "structure, formula, chemical name, physical properties ... [or] functional claim language ... when the art has established a correlation between structure and function."

Merely drawing a fence around the outer limits of a purported genus is not an adequate substitute for describing a variety of materials constituting the genus and showing that one has invented a genus and not just a species.

The majority conceded that WDR "possession" standards are not very enlightening but that applicants still need to show possession in the application by describing an invention and showing that "the inventor actually invented the invention claimed." Factors such as "the existing knowledge in a particular field, the extent and content of the prior art, the maturity of the science or technology, [and] the predictability of the aspect at issue" could be used to satisfy the WDR.

Such WDR factors mirror, or at least overlap with, however, a number of the Wands factors for enablement (state of the prior art, the skill of those in the art, the predictability of the art, and the guidance provided by the inventor, including the presence of working examples). The conflation of the WDR with the enablement requirement of $\$ 112$ also appears in the Patent Office's Manual (MPEP) and "Guidelines" used by examiners to assess patent applications. $^{2}$

Judge Lourie's own pen demonstrates how difficult it is to create WDR standards that do not also measure enablement. He pointed to

\footnotetext{
${ }^{2}$ Guidelines for the Examination of Patent Applications Under the 35 U.S.C. \$112, para. 1, 'Written Description Requirement, Manual of Patent Examination Procedures, M.P.E.P. \$\$ 2163(II)(A)(1)(a), 2163(II)(A)(3)(a) and 2164.01(a); "Written Description Training Materials" at 1-2 (2008) ("Guidelines," available at http://www.uspto .gov/web/menu/written.pdf.
} 
Ariad's disclosure of "decoy molecules" that can compete for NF- $\mathrm{B}$ binding when there are numerous NF- $\mathrm{BB}$-binding sites described in Ariad's application, but he complained that Ariad had not described using those molecules to reduce NF- $\kappa$ B activity. This "how to use" test is historically a test for enablement.

Judge Lourie quoted the tired language from the 1966 Brenner v. Manson (383 U.S. 519, 86 S. Ct. 1033, 16 L. Ed. 2d 69) decision that " $[\mathrm{A}]$ patent is not a hunting license. It is not a reward for the search but compensation for its successful conclusion." Then he concluded the Ariad v. Lilly decision: "Requiring a written description of the invention limits patent protection to those who actually perform the difficult work of 'invention'-that is, conceive of the complete and final invention with all its claimed limitations - and disclose the fruits of that effort to the public." No authority is cited for the requirement that only inventions that are "complete and final" can be patented.

Judge Newman concurred with the invalidity ruling on policy grounds, stating: "Basic scientific principles are not the subject matter of patents. ..." Judge Garjarsa also concurred but argued that Ariad's claims should be invalid for lack of enablement and there was no need to locate a separate WDR within $\$ 112$, because the "enablement requirement is a more than adequate vehicle for invalidating patent claims that are broader than their disclosure." Judge Linn dissented from the ruling of invalidity but agreed with Judge Garjarsa: "Any claim that uses purely functional language, or covers a broad genus without sufficient supporting examples, will not be enabled."

Judge Rader pointed to the majority's "undefined 'written description' doctrine" and accused them of ignoring the problems of "standardless decision making." He was worried that the ruling sets up conflicts with other areas of patent law, including the maxim that the claims cannot be construed so that they exceed the scope of the rest of the specification.

Judge Rader also noted possible interference with the productive tension between dominant or "blocking patents" and later improvement inventions. Judge Rader warned us that if "possession" is the rule, the value of blocking patents will disappear when improvement patents are issued. In essence, an improvement patent could invalidate earlier generic claims, when the inventor of an earlier-filed "blocking" patent cannot demonstrate adequate possession of the improvement later patented by another. According to Judge Rader, "Nowhere does [\$112, first] paragraph require that the inventor satisfy some quixotic possession requirement."

\section{Centocor v. Abbott: THE FEDERAL CIRCUIT TAKES THE NEW WDR OUT FOR A SPIN}

In the Centocor Ortho Biotech, Inc. v. Abbott Laboratories (636 F.3d 1341) (Fed. Cir. 2011) case, the Federal Circuit reversed a district court decision that Abbott's HUMIRA ${ }^{\circledR}$ product infringed a Centocor patent and, in so doing, obviated the $\$ 1.67$ billion in damages that Abbott would have owed Centocor. HUMIRA ${ }^{\circledR}$ is a fully humanized antibody against tumor necrosis factor $\alpha$ (TNF- $\alpha)$. Centocor had obtained U.S. Patent No. 7,070,775 claiming antibodies with a human constant region and a human variable region. However, Centocor needed to be able to claim "priority" to an earlier application in order to predate the filing date of Abbott's HUMIRA $^{\circledR}$ patent.

Applying the Ariad v. Lilly WDR standards, a three-judge Federal Circuit panel found no adequate description of a completely humanized antibody in the earlier-filed Centocor application, and thus no description adequate to support the later-issued patent claims. Instead, Centocor could only show actual possession of a half-human, half-mouse anti-TNF- $\alpha$ antibody.

Two aspects of this decision stand out. The first is how the "new" WDR has become an "easy button" for the Federal Circuit to dispose of what, in some cases, are pioneering biotech patents with broad claims. Courts need not resolve complex factual issues involving enablement issues when, as Judge Prost put it in the Centocor v. Abbott case, "A patent also can be held invalid for failure to meet the written description requirement based solely on the face of the patent specification." 
W.D. Woessner and R.A. Chadwick

The second is that even though the panel reaffirmed that actual possession (e.g., working experimental examples) is not required to meet the WDR, the panel dismissed Centocor's arguments that the application described the desired properties of their all-human antibodies, including the need for competitive inhibition of binding by a highly effective anti-TNF $\alpha$ mouse antibody. The panel found that Centocor's claims were no more than a "mere wish or plan for how one might search for a fully-human antibody that satisfies the claims," that is, an antibody with both a human constant region and a human variable region that had the recited binding affinity and neutralizing activity. In other words, the panel required that such an antibody actually be made or be in "possession" of the inventor.

Courts defining the WDR have made it manifest that "make it or fake it" are the only choices available to inventors of early-stage biotechnology. Centocor set forth quite clearly the properties that its antibody should possess using language that Judge Lourie indicated in UC v. Lilly might be sufficient to meet the WDR (e.g., a chemical name and physical properties). But even with testimony that the specification taught how to make and use human antibodies, and actually having made an antibody that had all the claimed properties but was only "half" human, Centocor still lost. Centocor had not made a wholly human antibody as of the filing date of the priority application, so the court found that Centocor did not have actual "possession" of an antibody with a human constant region, a human variable region, and the neutralizing and affinity activities recited in the claims. Centocor was not able to "fake," or theoretically construct, such a complex polypeptidyl structure.

This can be contrasted with small-molecule pharmaceutical patent practice, where, given even one structure, it is relatively easy for an organic chemist who is also a patent attorney to draw a related group of structures that typically can support a valid patent claim.

Fortunately for patent applicants, the Centocor $v$. Abbott court affirmed the long-standing practice of allowing claims to antibodies specific for a new (novel), well-characterized antigen (TNF $\alpha$ was not a novel antigen when Centocor filed its applications). Judge Prost wrote, "While our precedent suggests that written description for certain antibody claims can be satisfied by disclosing a well-characterized antigen, that reasoning applies to disclosure of newly characterized antigens where creation of the claimed antibodies is routine." However, the Centocor v. Abbott court still found the creation of fully humanized anti-TNF- $\alpha$ antibodies with the recited properties to be far from routine and, consequently still found that the Centocor application in question failed to meet the WDR.

The Federal Circuit declined to rehear the Centocor v. Abbott case before the full court, and the Supreme Court denied Centocor's petition for certiorari. Absent a divided opinion among the Federal Circuit judges, the Supreme Court was not likely to take up such an appeal, and by the time of the Centocor v. Abbott (2012) case, the Federal Circuit was no longer divided on this issue. Hence, this ruling may stand as a cautionary tale urging applicants to carefully choose only structural and functional features for which they can prove "possession" by way of actual synthesis and data.

\section{BSC v. J\&: THE WDR SPREADS ITS WINGS}

In June 2011, the Federal Circuit affirmed the invalidity of four J\&J patents for failure to meet the WDR (Boston Scientific Corp. v. Johnson \& Johnson (647 F.3d 1353) (Fed. Cir. 2011)). The patents claimed drug-eluting stents that are used to keep arteries opened by angioplasty from reclosing, or undergoing restenosis. The stents disclosed in the four patents all released rapamycin, a macrocyclic lactone, but the patent claims used broader terms to define the drug as a "rapamycin or a macrocyclic lactone analog of rapamycin" or a "macrocyclic triene analog of rapamycin." No such rapamycin analogs were disclosed in the patents.

$\mathrm{J} \& \mathrm{~J}$ argued that workable rapamycin analogs were known as of the filing date of the patent applications. In fact, BSC was using one of them in its stents. J\&J pointed to the court's 2005 holding in Capon v. Eshhar (418 
Patenting under Current WDRs

F.3d1349) (Fed. Cir. 2005), which affirmed that the patent claims satisfied the WDR even though they were drawn to DNA encoding single-chain variable fragment fusion proteins, but sequences of the single-chain variable fragment and its fusion partner were not specifically defined. However, in the Capon v. Eshhar case, many useful sequences were known, and the patent applications described procedures for identifying and obtaining the desired DNA segments and linking them together to form the desired chimeric DNA. Hence, the Caponv. Eshharcase supported the maxim that a patent specification need not disclose in detail, and preferably omits, material that is well-known to the art.

J\&J tried a similar tactic by asserting that the structure, mechanism of action, and biological activities of rapamycin and its analogs were set forth in the prior art, so it was not necessary for the patent to disclose "formulae or structures" or set forth "definitions, examples, or experimental models" of particular analogs. Although the term "analog" was, in effect, a functional description of a molecule, J\&J cited the Ariad $v$ Lilly case for the premise that "functional claim language can meet the written description requirement when the art has established a correlation between structure and function."

Writing for the BSC v. J\&J court, Judge Moore noted that a nearly infinite universe of compounds existed that were structurally similar to rapamycin and that even minor structural changes to the structure of rapamycin could have significant and unpredictable effects on functionality. Judge Moore also pointed to statements in J\&J's patents that could undermine a correlation between structure and function, such as "The precise mechanism of action of rapamycin in still under active investigation" and "The ideal agent for restenosis has not yet been identified." According to the BSC v. J\&J court:

The patent laws do not reward an inventor's invitation to other researchers to discover which of the thousands of macrocyclic lactone analogs of rapamycin could conceivably work in a drug eluting stent.

With no guidance at all in the specification as to how to properly identify or choose the claimed analogs, and in light of the unpredictability and nascent state of using drug-eluting stents to treat restenosis, we agree with the [summary judgment of invalidity for failure to satisfy the WDR].

Such statements indicate that the real problem with J\&J's patents was lack of enablement. Judge Gajarsa believed so, too. In concurring in part with the BSC v. J\&J (2011) ruling, Judge Gajarsa cautioned that "The majority's opinion further extends the [WDR] into the realm of enablement" and noted that an enablement analysis would have been "simpler and more appropriate."

Such rulings encourage courts to use the WDR as an "easy button" to eliminate patent claims that they feel are just too broad, by scrutinizing the words in the patent application rather than by having to engage in the more difficult task of examining factual issues of whether the application adequately teaches how to make and use the invention, as is required under an enablement analysis. Potentially more significantly, the BSC v. J\&J (2011) case may undermine attempts by patent holders to argue that knowledge available in the art can be used to meet the WDR.

\section{Wyeth v. Abbott: PICKING PLAINTIFF'S POISON}

Judges Moore and Bryson must have been listening to Judge Gajarsa, because on June 24, 2013, in the Wyeth v. Abbott Laboratories (720 F.3d) (Fed. Cir. 2013) case, a panel of Moore, Bryson, and Wallace invalidated two patents (U.S. Patent Nos. 5,516,781 and 5,563,146) drawn to methods of using rapamycin to treat or prevent restenosis for lack of enablement, without addressing the WDR issues raised.

This case was easily decided because Wyeth wanted to assert literal infringement by Abbott, which was using two rapamycin analogs, and was forced to agree that the claim term "rapamycin" was not to be limited to a single compound, sirolimus, but instead should be construed to include compounds "containing a macrocyclic triene ring structure produced by S[treptomyces] hygroscopius." The minute Wyeth 
W.D. Woessner and R.A. Chadwick

agreed to that claim construction, which it must have believed was needed to ensnare the defendants' use of analogs, the judicial panel could "pick its poison" from $\$ 112(1)$ to apply to Wyeth's claims. This time they picked nonenablement.

The Federal Circuit found that practicing the full scope of Wyeth's claims, at the time of filing (1992), would require undue experimentation to both synthesize and screen "tens of thousands of candidates" for antirestenosis effects. The court noted that Wyeth's patent discloses "only a starting point for further iterative research in an unpredictable and poorly understood field." This language could have been taken from the BSC v. J\&J (2011) opinion and, as noted by Judge Gajarsa, really fits a nonenablement ruling better than a WDR ruling.

\section{NOVOZYMES LOSES "POSSESSION" OF ITS ENZYME}

In the Novozymes A/S v. DuPont Nutrition Biosciences APS (723 F.3d 1336) (Fed. Cir. 2013) case, the district court judge overturned a jury decision that Novozymes' U.S. Patent No. $7,717,723$ met the WDR. A split panel of Federal Circuit Judges Schall, Bryson, and Rader affirmed the district court ruling, with Judge Rader dissenting.

By November 2000, Novozymes had identified "promising mutation sites" among the approximately 500 amino acid residues in $\alpha$-amylase, a useful starch-degrading enzyme. Using random protein design and random mutagenesis, Novozymes identified 33 sites at which a switch in amino acid residues might alter and hopefully improve the stability of the enzyme. The patent disclosed empirical data confirming the enhanced stability of variants harboring mutations at 16 positions that were identified through random mutagenesis. "Position 239" was identified as a useful location for mutation, and one analog, S239W, was prepared-although it was not found to have improved properties. Nor did 13 out of 19 substitutions at position 239 provide any improvement.

While Novozymes' applications were under Patent Office review, DuPont filed a patent ap- plication in November 2008 covering an S239Q variant that was thermostable. Novozymes' patent did not expressly disclose such an S239Q variant, but Novozymes had disclosed that variations at this position were useful to obtain thermostable enzymes. Upon learning that DuPont had a thermostable position $239 \alpha$-amylase variant, Novozymes filed and later obtained U.S. Patent No. 7,713,723, with claim 1:

1. An isolated variant of a parent alpha-amylase wherein:

The variant has at least $90 \%$ sequence identity to SEQ ID NO: 6,

The variant comprises a substitution of serine at position 239 relative to the parent alphaamylase...,

The variant has increased thermostability relative to the parent ... at $\mathrm{pH} 4.5,90$ degrees C. and 5 ppm calcium and has alpha-amylase activity.

This claim certainly seems to meet the requirements specified in UC v. Lilly (1997) and MPEP \$2163(II)(A)(3)(i): "Factors to be considered in determining whether or not there is sufficient evidence of possession include the level of skill and knowledge in the art, partial structure, physical and/or chemical properties, functional characteristics alone or coupled with a known or disclosed correlation between structure and function, and the method of making the claimed invention." No one disputed that the level of skill in the art was high or that the art was well developed. Paragraphs (a) and (b) of Novozymes' claim certainly recite "partial structure," and paragraph (c) recites both a physical property and a functional characteristic.

Novozymes argued that its facts were not like J\&J's from the BSC v. J\&J case because Novozymes' 2000 application expressly disclosed each limitation of the asserted claims. DuPont, on the other hand, argued that the WDR requires "the disclosure of the actual invention" and that the Novozymes application was no more than a "laundry list of potential solutions" of the stability problem. Even though Novozymes had filed its application 8 years before DuPont, DuPont accused Novozymes of using 
"hindsight to work backward ... to show that, given knowledge of the claimed invention, each limitation could be retroactively derived."

The Federal Circuit was convinced by DuPont, reasoning that "the supporting disclosure provides only generalized guidance listing several variables that might, in some combination lead to a useful result." The court referred to the BSC v. J\&J (2011) decision in which J\&J's patent "did not identify any such analogs or any reliable means for divining one, [and] the written description failed to demonstrate that the inventors were in possession of the claimed invention."

The Novozymes $v$. DuPont opinion doctrinally falls short at page 1351, where the majority says that "this case is very analogous to University of Rochester," in which the patent specification failed to disclose any compounds that could be used in the claimed methods to inhibit cyclooxygenase-2, except that they must be "non-steroidal" (University of Rochester v. G.D. Searle \& Co. (358 F.3d 916) (Fed. Cir. 2004)). The Novozymes factual situation is nothing like the University of Rochester situation. Novozymes did disclose many variants, including a whole genus of position 239 variants, albeit without proof (enablement) of stability of DuPont's exact variant. But other Novozymes variants were stable at $\mathrm{pH} 4.5$ and $90^{\circ} \mathrm{C}$ in $5 \mathrm{ppm}$ calcium, and it is as clear from the UC $v$. Lilly decision that recitation of structures, formulae, or physical properties should be sufficient to meet the WDR.

The Novozymes v. DuPont court never considered the "WDR factors" in detail, and instead reasoned that although Novozymes' application disclosed a myriad of variants, it provided insufficient "blaze marks" to demonstrate possession of the DuPont variant. The court essentially required actual reduction to practice of the position 239 variants, and the absence of a working example or express disclosure of the DuPont variant was a major, if not the only, basis for the court's holding that Novozymes' patent claims are invalid. For example, the court said that Novozymes' patent "contains no disclosure of any variant that actually satisfies the claims, nor is there anything to suggest that Novozymes actually possessed such a variant at the time of filing," and the application "nowhere describes the actual functioning, thermostable alpha-amylase variants" that Novozymes' claim defines. Finally, the panel gave weight to expert testimony that improved properties could not be predicted "without actually making and testing the variants."

Judge Rader authored a brief concurring opinion that begins:

\section{Although a separate written description require- ment and the vague notion of "possession" that it embodies, still troubles me, I write today to ask the court instead to give full attention to the rules that it has created.}

Judge Rader went on to argue that deference should have been given to the original jury verdict that Novozymes' claims satisfied the WDR, in view of the factual findings that supported it. According to Judge Rader, because of the high level of skill in the art, it would be routine, and not require undue effort, to make and to screen all of the possible mutations at the relatively small number of positions on the enzyme identified as responsible for the recited improved thermostability: "The court might also have credited the patentee with reducing the original 500 total amino acid positions down to a mere thirty-three." Judge Rader seemed to appreciate that justice might also be served by forcing the parties to share the benefits of the $\alpha$-amylase variants through preservation of Novozymes' patent.

\section{Sanofi-Aventis v. Pfizer: POSSESSION = INVENTION?}

In the Sanofi-Aventis v. Pfizer Inc. (App. No. 2012-1345, 2013; U.S. App. Lexis 22424) (Fed. Cir. Nov. 5, 2013) dispute to determine who first obtained a cDNA for the interleukin-13 (IL-13) receptor, Sanofi-Aventis had won the first-to-file race by filing its patent application on December 6, 1995. Pfizer filed its patent application later, on March 1, 1996. Nonetheless, the Board of Patent Appeals and Interferences awarded Pfizer priority of invention because Pfizer produced evidence that it had possession of an IL-13 receptor cDNA by October 16, 1995. The issue on appeal was that Pfizer did not 
W.D. Woessner and R.A. Chadwick

know the complete and correct sequence of the cDNA until after Sanofi-Aventis had filed its patent application.

On appeal, the Federal Circuit reminded us that under the rules effective until March 16, 2013, a patent is awarded to the first party to conceive and reduce an invention to practice. The standard articulated by the Federal Circuit for conception of a DNA invention is "possession and appreciation of the DNA segment that is claimed."

Pfizer had sequenced all 1143 nucleotides of its IL-13 receptor "clone 11 " on November 15 , 1995, about 3 weeks before Sanofi-Aventis's filing date. However, Pfizer discovered eight errors that were not corrected until December 12, 1995, with confirmation of the correct sequence by February 7, 1996.

Even so, the court agreed that Pfizer was first to invent because it had isolated clone 11, had appreciated that it encoded the full-length human IL-13 receptor, had identified clone 11's structural characteristics, and had correctly analyzed $>99 \%$ of the nucleotide sequence before Sanofi-Aventis filed its application. The fact that Pfizer had not corrected the sequence until after Sanofi-Aventis's filing date was not fatal because Pfizer was able to define the IL-13 receptor DNA "so as to distinguish it from materials, and to define how to obtain it." Thus, Pfizer won the fight and was awarded priority of invention.

Because the Sanofi-Aventis and Pfizer applications were filed before March 16, 2013, they were evaluated under the still-applicable firstto-invent laws. However, because the first-tofile rules went into effect on March 16, 2013, the courts now would almost certainly not make such a ruling for any application filed after March 16, 2013. Now, the winner is generally one who wins the race to file its application.

Actual possession of a protein in a vial can thus establish priority of invention even when only 379 out of 380 amino acids of the protein's sequence are known, as in the Sanofi-Aventis v. Pfizer (2013) case. But a patent applicant may fail to satisfy the written "description" standards when a patent applicant fails to actually isolate the one key variant that has only one amino acid difference from what it actually possess- es, as in the Novozymes v. DuPont (2013) case, even though the applicant knows the sequence of many protein variants, as well as the amino acid positions for making substitutions, and important functional characteristics of a protein.

\section{CONCLUSION}

The WDR is evolving one fact situation at a time, with entire classes of life sciences inventions moving in and out of its invalidity shadow. Two hypothetical fact patterns may illustrate the current WDR uncertainties.

In the first, an inventor isolates a new protein, factor $\mathrm{X}$, but knows nothing about its structure, except that it is not an antibody. However, the protein binds to a receptor site on prostate cancer cells and blocks their division completely. If the inventor now files, the inventor has actual possession but can only claim the protein functionally. If the inventor deposits some of factor $\mathrm{X}$ in a recognized depository, the claim to "factor X" and its function could meet the WDR "possession" standard. If the inventor fails to deposit prior to issuance, the claims would be invalid for failure to satisfy the WDR, and a later related application that fully characterizes factor $\mathrm{X}$ would not be entitled to the filing date of the parent. The inventor would not receive a patent.

In the second hypothetical case, an inventor uses computational chemistry to identify consensus sequences that are responsible for the enzymatic activity of a protein encoded by a series of related plant genes. The software developed by the inventor then "mixes and matches" the consensus sequences to optimize the bioactivity of the enzyme, arriving at a genus of hypothetical high-activity enzymes, all defined by complete sequences. If the inventor files at this point, with adequate directions as to how to assemble the synthetic enzymes, he has filed a presumably enabling specification with complete structural data, but with no actual reduction to practice. Is this an example of a specification that should fail the heightened WDR or one that should meet the precise definition test of the new WDR? Do we need the enablement (Wands) factors to evaluate the ability of the 
specification to place the invention in the hands of the public? Should this inventor, who never walked into a laboratory, receive a patent while the inventor of factor $\mathrm{X}$ is left with nothing but the satisfaction of curing cancer?

If factor $\mathrm{X}$ is an antibody and the target antigen is novel, the Federal Circuit has indicated that antibody claims can meet the WDR. But what if it is a hormone, or a small molecule, or an "anti-inflammatory steroid"? Now judges have created rules requiring review of endless fact situations on the basis of five words in $\$ 112$ that provide no guidance whatsoever as to what they require, beyond some degree of correspondence between the specification and the claims. Maybe mere correspondence between specification and claims is a more certain and judicially economical WDR standard.

If we must all live with a possession standard, functional generic claiming is no longer an option for chemical and biological inventions. The Federal Circuit tells us that it is not enough to disclose how to screen for compounds that exhibit a particular bioactivity. In the past, the Patent Office would allow a functional generic claim along the lines of "A method comprising treating condition $\mathrm{x}$ by administering an effec- tive amount of an inhibitor of enzyme z" so long as the specification disclosed a number of working examples of inhibitors of enzyme $z$. The inhibitors often were set forth structurally in a more specific dependent claim. But now, as stated in the Ariad v. Lilly opinion, we cannot "preempt the future before it has arrived.... [The description requirement] is part of the quid pro quo of the patent grant and ensures that the public received a meaningful disclosure in exchange for being excluded from practicing an invention for a period of time."

A new division of opinion may result from the group of judges recently added to the Federal Circuit, but for now the fate of any appeal from a WDR decision will depend entirely on the panel that the appellant draws. Whether or not the interested public agrees with the viability of the Wands enablement requirements, they have proved to be a workable test for meeting the make-and-use requirement of $\$ 112$. Do the recent WDR possession standards provide justice or confusion? Court decisions have not clarified the requirements of the WDR, and instead seem to be moving WDR jurisprudence in a direction that does not stimulate early-stage biotechnology with the reward of patent. 


\section{$\&_{\mathrm{CSH}}^{\infty} \&$ Cold Spring Harbor

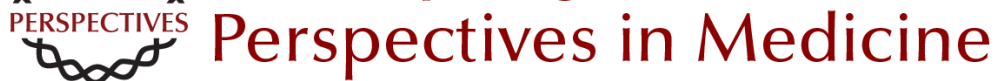

\section{Must an Inventor "Possess" an Invention to Patent It?}

Warren D. Woessner and Robin A. Chadwick

Cold Spring Harb Perspect Med 2014; doi: 10.1101/cshperspect.a020867 originally published online September 18, 2014

\section{Subject Collection Intellectual Property in Molecular Medicine}

Patentability of Stem Cells in the United States Sarah E. Fendrick and Donald L. Zuhn, Jr.

Inventorship and Authorship Antoinette F. Konski and Linda X. Wu

The Patentability of Stem Cells in Australia Jenny Petering and Prue Cowin

Impact of America Invents Act on Biotech Intellectual Property

Amanda Murphy, Michael Stramiello, Jonathan Stroud, et al.

Introduction to Intellectual Property: A U.S.

Perspective

Amanda Murphy, Michael Stramiello, Stacy Lewis, et al.

The Role of Regulatory Agencies and Intellectual Property: Part I

Kevin E. Noonan

Canada's Patented Medicines (Notice of Compliance) Proceedings and Intellectual

Property

Henry Bian and Conor McCourt

Patentability of Genes: A European Union

Perspective

Paul Cole
The Impact of Myriad on the Future Development and Commercialization of DNA-Based Therapies and Diagnostics

Michele Wales and Eddie Cartier

Protecting Traditional Knowledge Related to

Biological Resources: Is Scientific Research

Going to Become More Bureaucratized?

Prashant Reddy and Malathi Lakshmikumaran

Protecting Trade Secrets in Canada

Noel Courage and Janice Calzavara

Inherent Anticipation in the Pharmaceutical and

Biotechnology Industries

Michael Goldman, Georgia Evans and Andrew Zappia

The Role of Regulatory Agencies and Intellectual

Property: Part II

Kevin E. Noonan

Baseball Bats and Chocolate Chip Cookies: The Judicial Treatment of DNA in the Myriad Genetics Litigation lan Binnie and Vanessa Park-Thompson

The Impact of Myriad and Mayo: Will

Advancements in the Biological Sciences $\mathrm{Be}$

Spurred or Disincentivized? (Or Was Biotech

Patenting Not Complicated Enough?) Jennifer Gordon

Trade Secrets in Life Science and Pharmaceutical Companies

Tara Nealey, Ronald M. Daignault and Yu Cai

For additional articles in this collection, see http://perspectivesinmedicine.cshlp.org/cgi/collection/ 